\title{
Psychoactive Substances and Mobile Virtual Spaces: Impact on Teaching and Learning of Anatomy
}

\author{
Sustancias Psicoactivas y Espacios Virtuales Móviles: \\ Impacto en la Enseñanza y Aprendizaje de la Anatomía
}

\author{
Martin J. Mazzoglio y Nabar*; Rubén D. Algieri**; Elba B. Tornese ${ }^{* * *}$; Claudia G. Dogliotti*;

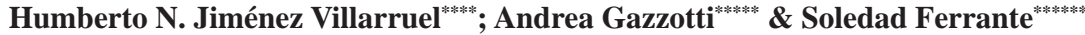

MAZZOGLIO Y NABAR, M. J.; ALGIERI, R. D.; TORNESE, E. B.; DOGLIOTTI, C. G. JIMÉNEZ, V. H. N.; GAZZOTTI, A. \& FERRANTE, S. Psychoactive substances and mobile virtual spaces: impact on teaching and learning of anatomy. Int. J. Morphol., 33(4):1487-1493, 2015.

SUMMARY: In preliminary studies, we recorded increased prevalence of psychoactive substances use in students retaking classes and with work activities. This constantly growing university population showed a greater use of mobile virtual spaces (mVS). The objective was to evaluate the adhesion characteristics, implications and impact of these factors in the teaching and learning process of anatomy. A cross-sectional observational study using standardized and anonymous survey on 326 students. Statistical parameters were applied and ethical and legal requirements were met. Forty-five percent reported that they used substances to increase the hours of study, highlighting coffee, energy drinks, psychoactive drugs (modafinil) and acetylsalicylic acid (ASA). Working hours were proportional to the amount of substances. Among those students retaking classes, this variable was consistent with the use of psychoactive drugs (modafinil: $r=-0.88$; ASA: $r=-0.73$ ). We recorded that the increased prevalence of psychoactive drugs use was associated with increased adherence to mVS. Work activity was crucial in the results of these factors, which had impact on attentional educational sphere.

KEY WORDS: Anatomy; Psychoactive substances; Mobile virtual spaces.

\section{INTRODUCCIÓN}

Everybody knows that to increase cognitive performance before an exam at the university, many students use psychoactive substances to increase waking hours and attentional capacity (Carrillo-Larco, 2012; Finger et al., 2013; Mazzoglio y Nabar et al., 2011; Vera Navarrete, 2012). But these substances interfere with the formation of engrams (a substrate of long-term and associative memory), interfere with learning and can cause drug dependency and intellectual performance involvement (Algieri et al., 2014; Buckingham, 2003; Duart \& Sandra, 2000; Geddes, 2004).
While providing a clinical response in the short term, they can lead to dependence and altered mental performance, especially attentional and mnemonic level impact on executive function, among other consequences which affect both individual health and social (Mazzoglio y Nabar et al.; Vera Navarrete).

The social fabric developed in Argentina presently in university education is not the same in which it was created; many political, economic and social causes have

* Médico, UBA. Especialista en Psiquiatría. Magister en "Neurociencia y Biología del Comportamiento", Universidad de Murcia. Docente Adscripto de la Facultad de Medicina-UBA. Jefe de Trabajos Prácticos de Anatomía, III Cátedra de Anatomía, Facultad de Medicina-UBA. Docente Auxiliar de Farmacología y de Psiquiatría, Facultad de Medicina, Universidad de Buenos Aires, Buenos Aires, Argentina,

** Médico, UBA. Especialista en Cirugía General. Profesor Adjunto Regular de Anatomía, Facultad de Medicina, UBA. Profesor Adjunto a cargo de Anatomía e Histología, UM. Jefe de Servicio de Cirugía, HAC, Buenos Aires, Argentina,

*** Médica, UBA. Doctora en Medicina, Médica Psiquiatra y Médica Legista de la UBA. Profesora Titular de la Universidad Abierta Interamericana. Profesora Adjunta Equiparada de Anatomía y Docente Autorizada de Salud Mental, Facultad de Medicina, UBA. Jefa de Servicio del Hospital Neuropsiquiátrico "Dr. Braulio A. Moyano", Buenos Aires, Argentina,

**** Médico, UBA. Especialista en Cirugía y en Cirugía Plástica y Reparadora, UBA. Jefe de Trabajos Prácticos de Anatomía, III Cátedra de Anatomía, Facultad de Medicina, Universidad de Buenos Aires, Buenos Aires, Argentina.

****** Médica, UBA. Especialista en Medicina Física y Rehabilitación Física, UBA. Docente Adscripta de la Facultad de Medicina-UBA. Jefe de Trabajos Prácticos de Anatomía, III Cátedra de Anatomía, Facultad de Medicina, Universidad de Buenos Aires, Buenos Aires, Argentina.

${ }^{* * * * * * * *}$ Médica, UBA. Especialista en Cirugía. Jefe de Trabajos Prácticos de Anatomía, III Cátedra de Anatomía, Facultad de Medicina, Universidad de Buenos Aires, Buenos Aires, Argentina. 
influenced the country in the last century (Algieri et al., 2014; Buckingham; Correa Gorospe, 2005; Geddes; Levis, 2007; Marenco \& Urvoy, 1975). Students work many hours a day to the detriment of their hours of rest and sleep, preparedness levels prior to university entry are poor and create difficulties in learning abstract concepts. Therefore, social and academic policies have been created for students and their development, at the start of school through subjective management in the context of information technology and education.

The qualitative parameters related to population issues and virtual learning environments (VLEs) use introduced bias in research results of the application at university facilities. The diversity of university population in Argentina determined that the technological means for logins are multiple (PC, tablets, smartphones), consistent with the educational purpose and economic and occupational characteristics of students.

In preliminary studies, we recorded increased prevalence of psychoactive substances use, in students retaking classes and with work activities. This constantly growing university population showed a greater use of mobile virtual spaces (mVS).

The objective was to evaluate the adhesion characteristics, implications and impact of these factors in the teaching and learning process of Anatomy.

\section{MATERIAL AND METHOD}

An observational and cross-sectional study was carried out by implementing a standardized and anonymous survey on 366 college students pertaining to the 2013 period of Human Anatomy Subject from $3^{\text {rd }}$ Chair of Anatomy at the University of Buenos Aires. The population characteristics are shown in Table I. Statistical parameters

Table I. Population characteristics of the sample.

\begin{tabular}{lcc}
\hline Age & 19 years & $23.77 \%$ \\
& 20 years & $40.98 \%$ \\
& 21 years & $21.31 \%$ \\
& $>21$ years & $13.94 \%$ \\
Sex & Female & $71.31 \%$ \\
& Male & $28.69 \%$ \\
Origin & Argentine & $94.26 \%$ \\
& Foreing & $5.74 \%$ \\
Work? & Yes & $37.71 \%$ \\
& No & $62.29 \%$ \\
How many hours a day? & $<4$ hours & $4.35 \%$ \\
& $4-8$ hours & $73.91 \%$ \\
How many days a week? & $>4$ hours & $21.74 \%$ \\
& $<5$ days & $25.41 \%$ \\
It works simultaneously & 5 days & $50.82 \%$ \\
while studying? & $>5$ days & $23.77 \%$ \\
It is your first time coursing & Yes & $40.98 \%$ \\
human anatomy? & No & $59.02 \%$ \\
How many hours do you & Yes & $68.03 \%$ \\
bring a week to study & No & $31.97 \%$ \\
Anatomy? & $<15$ hours & $30.33 \%$ \\
& 15 hours & $19.67 \%$ \\
& 20 hours & $28.69 \%$ \\
& 25 hours & $12.29 \%$ \\
& $>25$ days & $9.02 \%$ \\
\hline
\end{tabular}

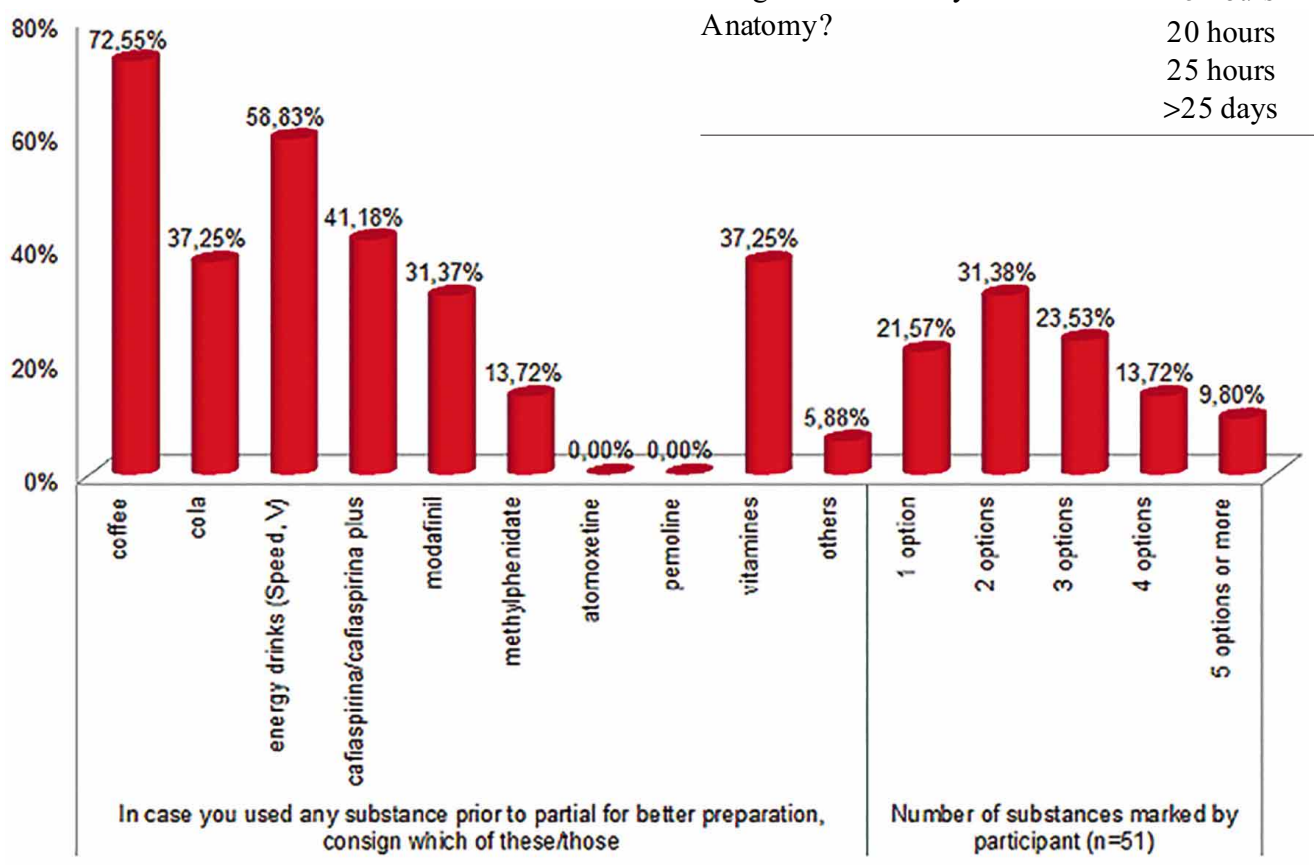

Fig. 1. Percentage of substances used by students and amount of choice of the same. 
were applied to results and ethical and legal requirements were complied (Good Clinical Practices-GCP-current provisions and adherence to ethical principles arising from the Declaration of Helsinki).

\section{RESULTS}

The $45 \%$ reported to have used substances in order to increase the hours of study, highlighting coffee (72.5\%), energy drinks (58.83\%), psychotropic drugs $(45.09 \%)$ and acetylsalicylic acid (ASA) (41.18\%). The 54.91\% ( $\mathrm{n}=28)$ chose between 2 and 3 options from the list of substances; modafinil (31.37\%) and methylphenidate (13.72\%) (Fig. 1) use prevailed among psychotropic drugs, by a friend's recommendation $(37.25 \%)$ and by prescription $(33.33 \%)$ (Fig. 2).

Among students with work activities (62.46\%), although the login was quantitatively higher from work desktops or from public access, we recorded a higher proportion of logins from mobile devices (notebook and netbook) with connection via public or mobile WiFi, followed by login using tablet PC and smartphone. In this subgroup, we recorded more variety of devices for logging in the virtual space with a mostly mobile connection (not exclusive) (Figs. 3 and 4).

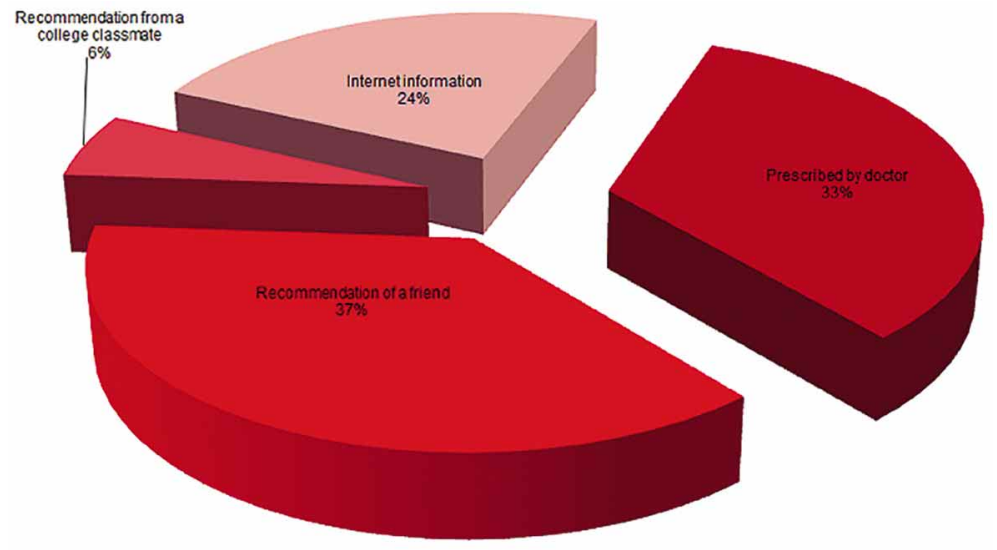

Fig. 2. Percentage of responses about media access to psychoactive substances.

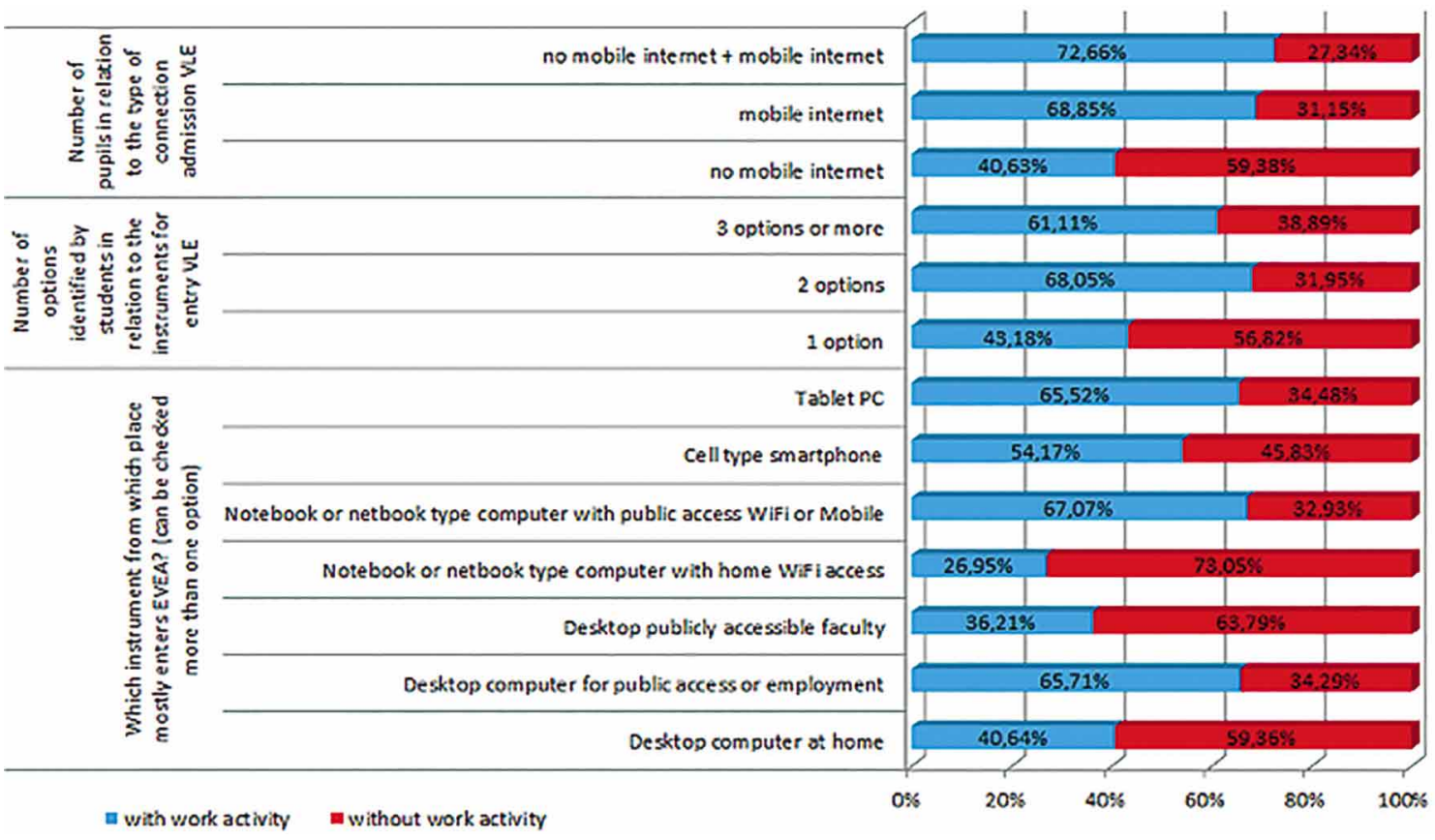

Fig. 3. Quantitative results of responses related to the technological tools and connection means used for entry into VLE specifying the employment status of students. 
MAZZOGLIO Y NABAR, M. J.; ALGIERI, R. D.; TORNESE, E. B.; DOGLIOTTI, C. G. JIMÉNEZ, V. H. N.; GAZZOTTI, A. \& FERRANTE, S. Psychoactive substances and mobile virtual spaces: impact on teaching and learning of anatomy. Int. J. Morphol., 33(4):1487-1493, 2015.

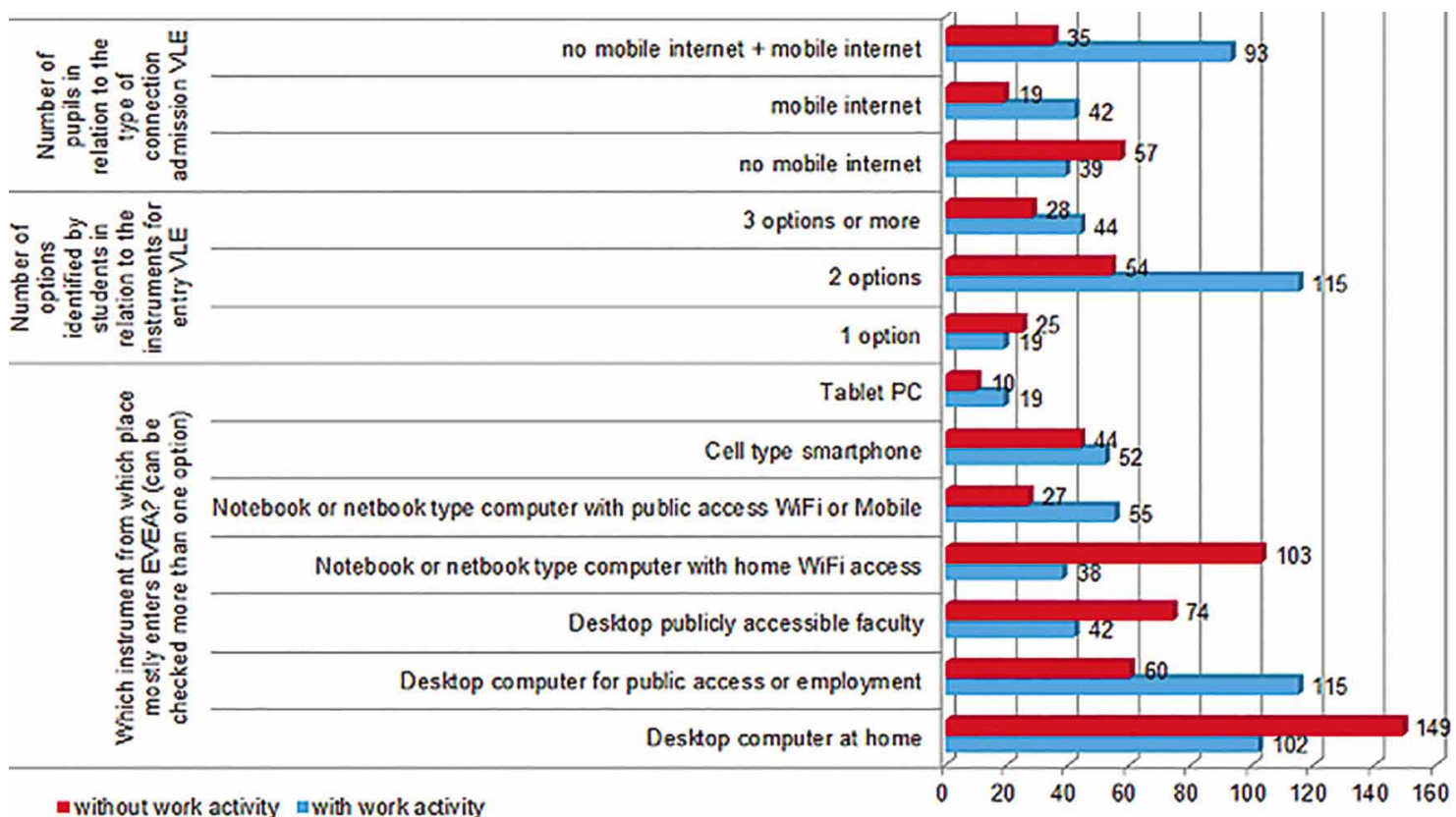

Fig. 4. Percentage of responses related to the technological tools and connection means used for entry into VLE specifying the employment status of students.

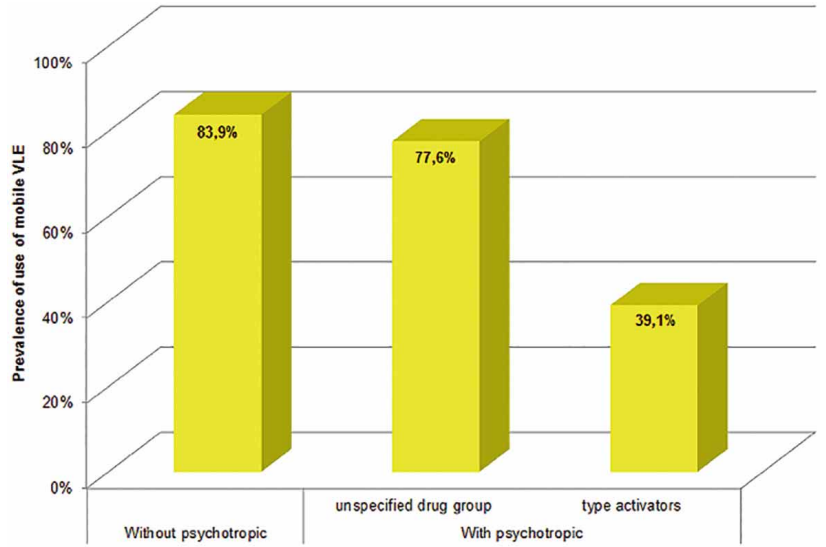

Fig. 5. Prevalence of use of mobile VLE as student group that used psychoactive drugs or not.

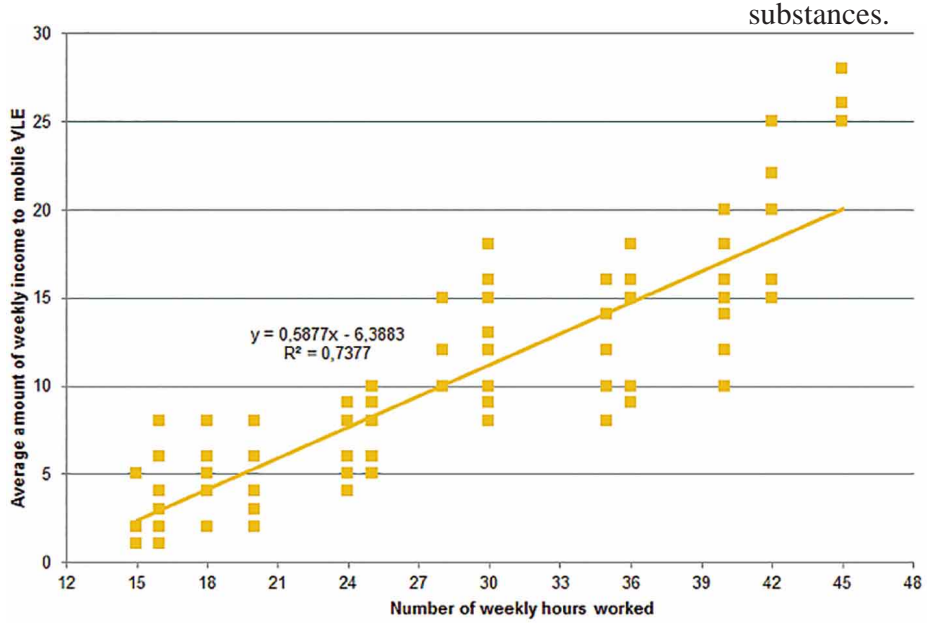

Fig. 7. Correlation between the amount of weekly income to the mobile EVEA depending on the number of work hours of students. 


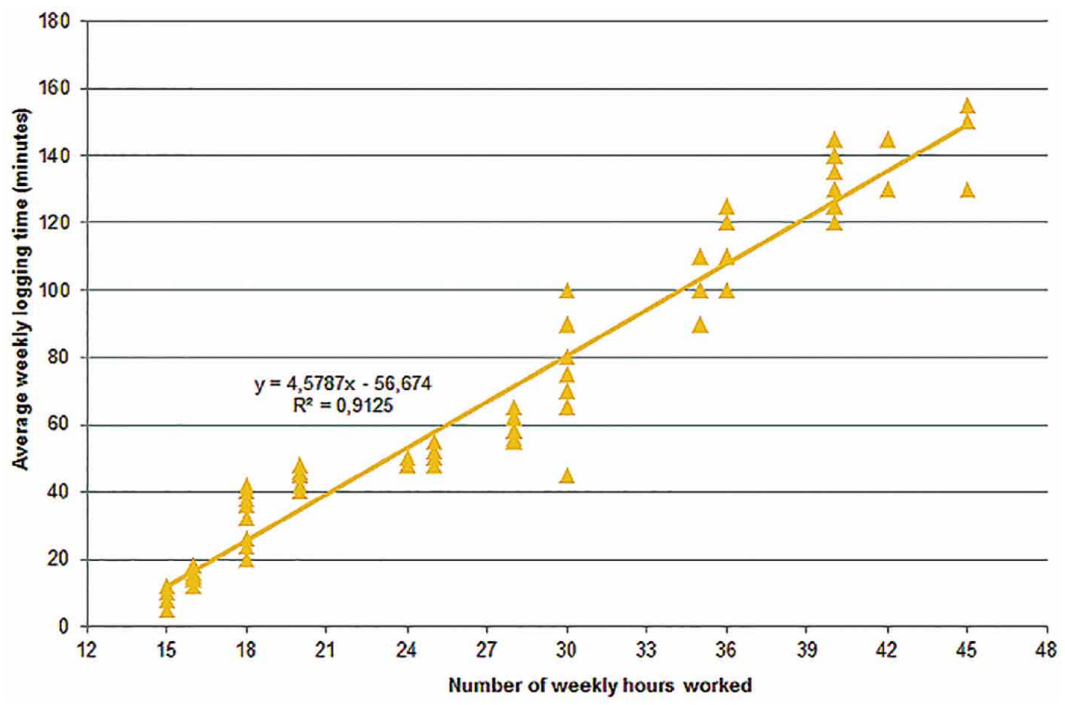

Fig. 8. Correlation between weekly time logging on mobile EVEA depending on the number of work hours of students.

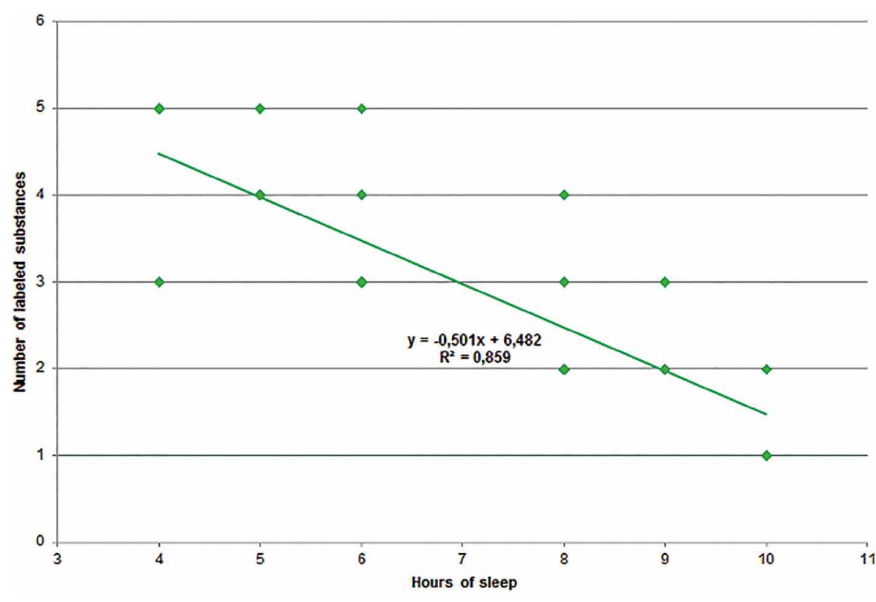

Fig. 9. Correlation between the amount of labeled according to sleep in the group of students who repeated the matter.

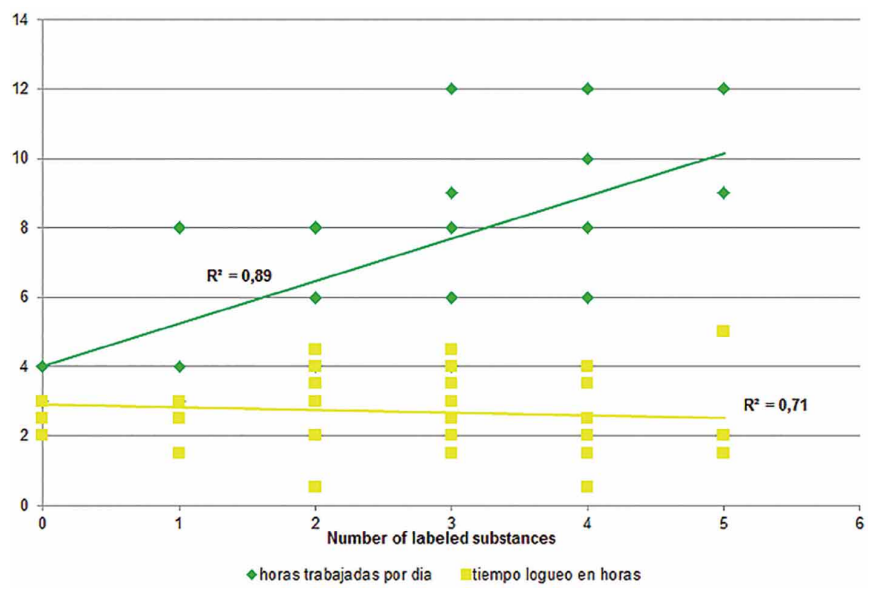

Fig. 10. Correlation between the amount of substances used and working hours per day and logging.

In reference to the above, $30.74 \%$ felt that mVLS helped in their learning process because it allowed them to share study information among peers, the $25.78 \%$ said that similar exercises helped them to consolidate knowledge (images and clinical cases of a same subject), $20.31 \%$ said that it allowed them to interrelate concepts quickly with images and links to other sites of Anatomy and the $19.9 \%$ claimed that it allowed them to increase their attention when studying in a virtual and social environment with impact on adherence with subject.

Students who used psychoactive drugs, especially activators (modafinil and methylphenidate), showed a decreased prevalence of mVLS use (Fig. 5).

Students with work activities showed an increased use of substances and showed positive correlation between substance use and the number of daily hours worked $\left(r^{2}=0.89\right)$ (Fig. 6), as well as between the number of hours worked per week and the mean login per week $\left(r^{2}=0.74\right)$ and the average of weekly login time $\left(r^{2}=0.91\right)$ (Figs. 7 and 8$)$.

Among students who retake classes, a lower average of hours of sleep that presented a negative correlation with a psychoactive substance use $(\mathrm{r}=-0.86)$ (Fig. 9) was shown.

The amount of psychoactive substances used related to the number of hours worked per week $\left(\mathrm{r}^{2}=\right.$ $0.89)$ and weekly login time in mVLE $\left(r^{2}=0.71\right)$ (Fig. $10)$. 


\section{DISCUSSION}

The social interference of new technologies produces significant changes in the modes of access to information, work with it in the construction of knowledge and build social relationships among users within a virtual classroom.

The impact of ICT not only led to the transformation of daily practices, but also redefined the educational paradigm in which virtual spaces were developed applied to teaching through an "inclusive-education" concept. The impact was not only unidirectional but also changed the student user's subjective position and in their cognitive structure, enabling their understanding of instructional resources as a means for learning (Duart \& Sandra; Levis; Marenco \& Urvoy).

In our work, we determined how students with work activities adapt the educational resources to their schedule and accessibility, generating mobile virtual spaces (mVLS) without limit as regard time and place of login. The correlations showed and determined that the amount of labor hours were proportional to the amount of logins per week and to the time of logins of these students.

The implementation of ICTs, especially the VLS, in our Department of Anatomy emerged as a restorative pedagogical project against the low percentage of students who attend classes without having read the subject of study for the Practical Work and a few who said to have memorized just a few concepts.

International and national preliminary research showed that EVEA increased adherence, concentration and attention when studying (Algieri et al., 2008; Arteaga \& Pimienta; Correa Gorospe; Levis; Tornese et al., 2012), through synchronous stimulation (visual, auditory, associative) of analogous sensory pathways, and thus increase and reinforce learning capacity (Arteaga \& Pimienta; Sweller et al., 1998). For effective and meaningful memory consolidation, a more open attentional field is required (Paas et al., 2004). Attentional brain activations by reverberating circuits are used to strengthen and complement mnesic engrams in fronto-temporal-parietal crusts so as to integrate knowledge based on learning and divergent stimuli. Instructional strategies that allow such increases are problem-based learning, clinical-surgical and clinical-imaging cases, and collective glossaries with the purpose of achieving an efficient uptake of attention, focused on maintenance of sustained and selective attention in each exercise that enables executive cognitive learning based on repetition and association in various pedagogical scenarios (forums, self- assessments, descriptions of clinical correlates), thereby generating skills in students.

We recorded that $65 \%$ of respondents began to consolidate concepts three days before the exam, which makes associative processes difficult since there is limited time and it is inhibited by the few hours of sleep that will not allow consolidation of mnesic circuits. Another factor limiting the generation of mnemonic engrams and subsequent learning is the increased use of benzodiazepines by students. They are associated with a deleterious effect on learning by altering cognitive mechanisms (primarily anterograde memory), among other disadvantages. Regarding the high use substances used to increase the hours of study, although they activate the nervous system, there is no evidence that they improve the storage capacity and associative learning, but they do increase waking hours with an increase of sustained attention and inhibition mechanisms necessary to focus attention on relevant issues, without mentioning the potential dependence, tolerance generated and biochemical interactions, since $55 \%$ of respondents reported to have used between 2 and 3 substances for this purpose (Jufe, 2006; Molholm et al., 2006; Paas et al.; Sweller et al.).

The dissemination and accessibility of the population to smartphones and tablet PC enabled its wide dissemination among college students. As observed in the results of this study, users of technologies redefine not only the teaching aim but also the utility, purpose and objective of the teacher. One of these goals is education, from the update data submitted or static information, and cooperative learning in virtual environments online. The high-definition images access points and Wi-Fi helped the students use TC as an instructional resource in the process of teaching and learning. The constraints presented to this use are related to economic factors, connection speed and local insecurity; for these reasons is its use was highly prevalent in public places.

The VLS, particularly the mobiles (mVLS), permit a bidirectional exchange between students and teachers with their tutors and synchronous online form, together with the importance of social interaction for learning of higher psychological processes, already postulated by Vygotsky (Carretero, 2009) and tested in many more recent studies (Burgos \& Koper, 2005; Correa Gorospe). In our work, the aforementioned possibility of communication, rapid interplay of concepts and the possibility of consolidation by different exercises were the characteristics most valued by students. These facts reaffirm that effective and meaningful learning is achieved in a social context, characterized by collaboration, feedback and discussion. 
CONCLUSIONS. We evidenced that the high prevalence of substance use was associated with increased adherence to mobile virtual learning spaces. Work activity was determined in the results of these variables, which had an impact on substance use and educational level in the attentional field. We observed that those students who had not used psychoactive activators presented a higher use of mobile virtual spaces, a fact that will be the subject of future investigations.

MAZZOGLIO Y NABAR, M. J.; ALGIERI, R. D.; TORNESE, E. B.; DOGLIOTTI, C. G. JIMÉNEZ, V. H. N.; GAZZOTTI, A. \& FERRANTE, S. Sustancias psicoactivas y espacios virtuales móviles: impacto en la enseñanza y aprendizaje de la anatomía. Int. J. Morphol., 33(4):1487-1493, 2015.

RESUMEN: En estudios preliminares registramos alta prevalencia de uso de sustancias psicoactivas en alumnos recursantes y con actividades laborales. Esta población universitaria, en constante crecimiento, presentó mayor utilización de los espacios virtuales móviles (mEVEA). El objetivo fue evaluar las características de adhesión, implicancia e impacto de dichos factores en el proceso de enseñanza y aprendizaje de la Anatomía. Estudio observacional y transversal mediante encuesta estandarizada y anónima en 326 alumnos. Se aplicaron parámetros estadísticos y se cumplió con requisitos ético-legales. El $45 \%$ refirió consumir sustancias para aumentar las horas de estudio, destacándose el café, energizantes bebidas, psicofármacos (modafinilo) y ácido acetilsalicílico (AA). Las horas laborales fueron proporcionales con la cantidad de sustancias, entre los recursantes dicha variable fue correlativa con el uso de fármacos psicoactivos (modafinilo: $\mathrm{r}=-0,88$; AA: $\mathrm{r}=-$ $0,73)$. Registramos que la alta prevalencia de consumo de sustancias psicoactivas se asoció con un incremento en la adherencia a los mEVEA. La actividad laboral fue determinante en los resultados de dichas variables, las cuales tuvieron impacto pedagógico en la esfera atencional.

PALABRAS CLAVE: Anatomía; Sustancias psicoactivas; Espacios virtuales móviles.

\section{REFERENCES}

Algieri, R. D.; Ferrante, S. \& Mazzoglio y Nabar, M. J. Implementación de TIC en la enseñanza universitaria de la anatomía del hígado: aspectos neurobiológicos y psicopedagógicos. Buenos Aires, Diego Levis Comunicación \& Educación, 2008. Available from: www.diegolevis.com.ar/ secciones/Articulos/tic_medicina.pdf

Algieri, R. D.; Mazzoglio y Nabar, M. J.; Dogliotti, C. G. \& Gazzotti, A. Social-economic factor as a determining factor of parameters of use and performance in A TLVE applied to anatomy teaching. Glob. J. Hum. Soc. Sci. Linguist. Educ., 14(1):44-54, 2014.

Arteaga, D. G. \& Pimienta, J. H. Memoria operativa y circuitos corticales. Rev. Fac. Med. (Bogotá), 54(4):248-68, 2006.

Buckingham, D. New media, new sites of learning. Brussels, Seminar: 'Media Literacy - Citizenship and Dialogue', European Commission, 2003. Available from: http://www.elearningeuropa.info/extras/pdf/ brussels_media_literacy.pdf

Burgos, D. \& Koper, R. Virtual communities, research groups and projects on IMS Learning Design. State of the art, key factors and forthcoming challenges. Relieve, 11(2):189-200, 2005.
Carretero, M. Constructivismo y educación. Buenos Aires, Paidós, 2009.

Carrillo-Larco, R. M. Modafinilo, internet y redes sociales: potencial uso en la vigilancia en salud. Rev. Med. Chile, 140(10):1367-8, 2012.

Correa Gorospe, J. M. La integración de plataformas de e-learning en la docencia universitaria: Enseñanza, aprendizaje e investigación con Moodle en la formación inicial del profesorado. Relatec Rev. Latinoam. Tecnol. Educ., 4(1):37-48, 2005.

Duart, J. M. \& Sandra, A. Aprender en la virtualidad. Barcelona, Gedisa, 2000.

Finger, G.; da Silva, E. R. \& Falavigna, A. Use of methylphenidate among medical students: a systematic review. Rev. Assoc. Med. Bras., 59(3):2859, 2013.

Geddes, S. J. Mobile learning in the $21^{\text {st }}$ century: benefit for learners. Knowledge Tree e-journal, 30(3):214-28, 2004.

Jufe, G. Psicofarmacología Práctica. Buenos Aires, Polemos, 2006.

Levis, D. Enseñar y aprender con informática. Medios informáticos en la escuela argentina. En: Cabello, R. \& Levis, D. (Eds.). Medios informáticos en la educación a principios del siglo XXI. Buenos Aires, Prometeo, 2007. pp.21-50.

Marenco, C. \& Urvoy, J. Informática y sociedad. Barcelona, Editorial Labor S. A., 1975.

Mazzoglio y Nabar, M. J.; Algieri, R. D.; Dogliotti, C. G.; Gazzotti, A. M.; Jiménez-Villarruel, H. N. \& Rey, L. M. Utilización de sustancias psicoactivas en alumnos de anatomía y su implicación en el aprendizaje. Educ. Med., 14(2):129-32, 2011.

Molholm, S.; Sehatpour, P.; Mehta, A. D.; Shpaner, M.; Gomez-Ramirez, M.; Ortigue, S.; Dyke, J. P.; Schwartz, T. H. \& Foxe, J. J. AAudio-visual multisensory integration in superior parietal lobule revealed by human intracranial recordings. J. Neurophysiol., 96(2):721-9, 2006.

Paas, F.; Renkl, A. \& Sweller, J. Cognitive Load Theory: Instructional implications of the interaction between information structures and cognitive architecture. Instr. Sci., 2004, 32(1-2):1-8, 2004.

Sweller, J.; Van Merrienboer, J. J. G. \& Paas, F. Cognitive Architecture and Instructional Design. Educ. Psychol. Rev., 10(3):251-96, 1998.

Tornese, E. B.; Mazzoglio y Nabar, M. J.; Algieri, R. D.; Dogliotti, C. G. \& Gazzotti, A. mEVEA: ¿Espacios de enseñanza sin límites? Rev. Docencia Univ., 13(1):57-67, 2012.

Correspondence to:

Martín Javier Mazzoglio y Nabar

Médico, UBA. Especialista en Psiquiatría

Magister en "Neurociencia y Biología del Comportamiento"

Jefe de Trabajos Prácticos, III Cátedra de Anatomía

Docente Auxiliar de Farmacología y de Psiquiatría

Facultad de Medicina

Universidad de Buenos Aires

ARGENTINA

Received: 29-01-2015

Accepted: 10-11-2015

Email: mazzoglioynabar@hotmail.com 